\title{
A brief observation of morphological and behavioral similarities between the Ichneumonidae wasp Cryptanura sp. and its presumed mimic, Holymenia clavigera (Heteroptera: Coreidae), in Brazil
}

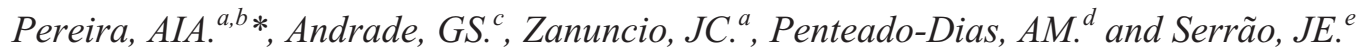 \\ ${ }^{a}$ Departamento de Biologia Animal, Universidade Federal de Viçosa, 36.571-000 Viçosa, MG, Brazil \\ ${ }^{b}$ Current address: Instituto Federal Goiano/Campus Urutaí, 75.790-000 Urutaí, GO, Brazil \\ ${ }^{c}$ Universidade Federal de Rondônia, 76.940-000, Rolim de Moura, RO, Brazil \\ ${ }^{d}$ Departamento de Ecologia e Biologia Evolutiva, Universidade Federal de São Carlos, 13.565-905 \\ São Carlos, SP, Brazil \\ ${ }^{e}$ Departamento de Biologia Geral, Universidade Federal de Viçosa, 36.571-000, Viçosa, MG, Brasil \\ *e-mail: aiapereira@yahoo.com.br
}

Received October 2, 2012 - Accepted November 21, 2012 - Distributed November 29, 2013

\begin{abstract}
Some insects use wasps as a model to mimic and previous studies showed cases of Batesian mimicry involving this insect group. However, this relation is poorly known between phytophagous bugs, such as coreids, and Cryptinae ichneumonids. We found in a seasonal secondary forest in Brazil two similar insects representing different orders. The mimic seems to be Holymenia clavigera (Herbst) (Heteroptera: Coreidae) and its model, Cryptanura sp. (Hymenoptera: Ichneumonidae). This study therefore investigated similarities in morphological and behavioural aspects between H. clavigera and the wasp Cryptanura sp. Holymenia clavigera and its ichneumonid model are impressively similar in colour, size, foraging behaviour and sympatric range. The spanning movements of antennae by the coreid bug, which strongly resemble the foraging behaviour of the wasp, were observed frequently. The findings indicate strong evidences that $H$. clavigera is a mimic of the Ichneumonidae wasp, Cryptanura sp.
\end{abstract}

Keywords: mimetism, model, phytophagous, passion fruit, Cryptinae.

\section{Uma breve observação de semelhanças morfológicas e comportamentais entre a vespa Ichneumonidae Cryptanura sp. e seu suposto mímico, Holymenia clavigera (Heteroptera: Coreidae), no Brasil}

\begin{abstract}
Resumo
Alguns insetos utilizam vespas como um modelo a imitar e estudos anteriores apresentaram casos de mimetismo Batesiano envolvendo este grupo de insetos. No entanto, esta relação é pouco conhecida entre percevejos fitófagos, tais como coreídeos, e ichneumonídeos Cryptinae. Encontramos em uma floresta secundária sazonal no Brasil dois insetos similares representando diferentes ordens. O mímico parece ser Holymenia clavigera (Herbst) (Heteroptera: Coreidae) e seu modelo, Cryptanura sp. (Hymenoptera: Ichneumonidae). Este estudo investigou semelhanças em aspectos morfológicos e comportamentais entre H. clavigera e a vespa Cryptanura sp. Holymenia clavigera e seu modelo ichneumonídeo são impressionantemente similares na cor, tamanho, comportamento de forrageamento e faixa simpátrica. Os movimentos abrangentes das antenas pelo percevejo coreídeo, que se assemelham fortemente ao comportamento de forrageamento da vespa, foram observados frequentemente. As descobertas apontam fortes evidências que H. clavigera é um mímico da vespa Ichneumonidae, Cryptanura sp.
\end{abstract}

Palavras-chave: mimetismo, modelo, fitófago, maracujá, Cryptinae.

\section{Introduction}

Mimicry occurs when a group of organisms, the mimics, have evolved to share common perceived characteristics with another group, the models, through the selective action of a signal-receiver or dupe (Franks and Noble, 2004). This phenomenon is one of the most celebrated examples of the power of natural selection $(\mathrm{Ev}-$ ans, 1965) occurring in both plants and animals but it is most prevalent among insects (Franks and Noble 2002; Ito et al., 2004). The mechanism by which palatable species take advantage of their similarity in appearance to those that are unpalatable, in order to avoid predation, is called Batesian mimicry (Bates 1862; Franks and Noble, 2004). 
Hymenoptera have species with different ecological functions such as ecto, endo and hyperparasitoids, gall miners, herbivores, pollinators, predators and eusocial species (Reis et al., 2008; Santos et al., 2009; Pereira et al., 2009; Ramalho et al., 2009) with well developed defense mechanisms against predators (Taniguchi et al., 2005). So, it is possible that a large number of their representatives must be involved, actively or not, in mimicry (Lorenzi et al., 2004).

Ichneumonidae wasps are one of the largest families of the Insecta class represented by 35 subfamilies and approximately 60.000 species (Wahl, 1993; Yu and Horstmann, 1997). A broad range of insects use these wasps as models to mimicry, perhaps due to the conspicuous habits of their representatives (Rettenmeyer, 1970) and because these parasite wasps have acquired an important evolutionary tool against natural enemies: the sting. So, the mimics that are not able to sting, or that have no efficient defensive apparatus, may resemble wasps to help deter predation. Once predators have learned to avoid the "true wasps", they similarly avoid the mimics (Golding et al., 2005). In general the mechanisms involving the mimicry phenomenon in insects are not restricted to visual signals (e.g., colour) and more than one type of signal may be employed such as morphological, chemical and behavioural ones (Flach et al., 2006).

This study reported morphological and behavioural aspects of the phytophagous bug Holymenia clavigera (Herbst) (Heteroptera: Coreidae), a pest of passion vine species (Passifloraceae) in Brazil, which strongly resembles the poorly-known ichneumonid wasp Cryptanura sp. (Hymenoptera: Ichneumonidae).

\section{Material and Methods}

\subsection{Area}

The study was conducted in a 20 ha fragment of native forest (semideciduous seasonal forest) of the Department of Animal Biology of the Federal University of Viçosa (UFV) in Viçosa, Minas Gerais State, Brazil at $20^{\circ} 45^{\prime} \mathrm{S}, 42^{\circ} 51^{\prime} \mathrm{W}$ and an altitude of $651 \mathrm{~m}$. This area has native and exotic species, including Psidium guajava, Psidium cattleianum and Eucalyptus spp. (Myrtaceae) and other arboreal and herbaceous plants with a floristic pattern similar to that described by Marangon et al. (2003). Mean annual temperature was $14.6^{\circ} \mathrm{C}$ to $21.8^{\circ} \mathrm{C}$ and annual rainfall of $1,220 \mathrm{~mm}$.

\subsection{Sampling Cryptanura sp. and H. clavigera adults}

Samplings were conducted from January 2007 to June 2007 including the rainy and hot seasons which are expected to be the main fly season for most Hymenoptera species from Viçosa. The sweeping vegetation was used to sample the specimens through an entomological vacuum glass $(150 \mathrm{~mL})$. However, due to the intense foraging habit of ichneumonid wasps near the leaf litter, and the high labour effort required by sweeping, yellow tray traps were additionally used.
Samples were taken along two transects, each one $200 \mathrm{~m}$ long by $20 \mathrm{~m}$ wide with an area of $8000 \mathrm{~m}^{2}$ (Zanuncio et al., 2004; Reis et al., 2008). The collector initially crossed the transect to recognise the path. After this, each transect was walked slowly from 09:00 to 12:00 considering especially the area and its sides. A total of 12 samples were taken monthly on random days. Collecting time was chosen due to the peak of ichneumonid wasps foraging (AIA Pereira, personal observations). Only H. clavigera and Cryptanura sp. adults were collected, including those remaining on leaves, branches or any other substrate. We did not keep rigorous tracks on the host species of the ichneumonid wasp. The yellow tray traps were a plastic rectangular $31 \mathrm{~cm}$ long, $25 \mathrm{~cm}$ wide and $6 \mathrm{~cm}$ high. Fifteen yellow tray traps were installed on the ground spacing $10 \mathrm{~m}$ between them.

All insects collected were stored in ethanol $70 \%$ and voucher specimens were deposited at the entomological collections of the Regional Museum of Entomology of the UFV and at the Federal University of São Carlos and at the Federal University of São Carlos, São Paulo state.

\subsection{Morphometrics}

Thirty morphological characters of $H$. clavigera and Cryptanura sp. were compared because they were easily recognised. Specimens of both species were measured with an ocular micrometer (Wild Heerbrugg 20x) in a Leica MZ-8 stereomicroscope and millimetres were used as the standard unit. The character terminology used was that of Zúñiga-Ramírez (2004).

\subsection{Behavioural Notes}

Behavioural notes of Cryptanura sp. were taken a few seconds before its capture by sweeping vegetation. Observations on the behaviour of $H$. clavigera were made in the same way in the area studied and additionally in a three year-old yellow passion fruit orchard at the Fruit Department (UFV) spaced 2.5 x $5.0 \mathrm{~m}$.

Photographs of $H$. clavigera and Cryptanura sp. adults were taken in the field with the macro mode of a Sony DSC-W70 Cyber-shot (7.2 megapixels) digital camera and detailed photographs were taken using the magnification of up to $20 \mathrm{x}$ with a stereomicroscope manually coupled with the lens of a camera directly to the ocular of the microscope.

\section{Results}

A total of 22 specimens were collected with Cryptanura sp. $(\mathrm{n}=18)$ being more abundant than $H$. clavigera $(\mathrm{n}=4)$. Samplings through sweeping vegetation collected more insects $(\mathrm{n}=16)$ than yellow tray traps $(\mathrm{n}=6)$ (Figure $1 \mathrm{~A}$ and B). Both methods were used to collect the ichneumonid wasp but yellow tray traps did not attract the bugs (Figure 1A). The number of Holymenia clavigera and its model are similar in size and shape with fourteen morphometric characters being similar between them (Table 1). Only the lengths of the first antennomere $(F=271.06 ; p=0.003)$, compound eyes 

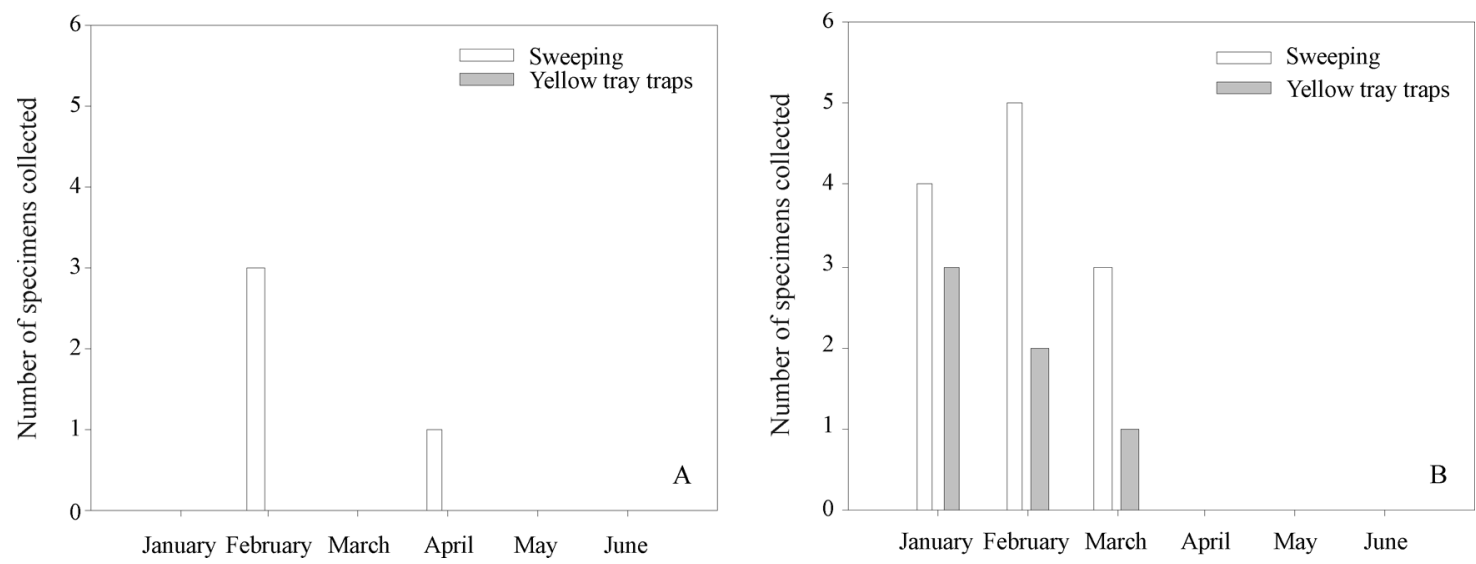

Figure 1 - Number of specimens of Holymenia clavigera (Heteroptera: Coreidae) (A) and Cryptanura sp. (Hymenoptera: Ichneumonidae) (B) collected by sweeping vegetation and yellow tray traps in a secondary forest area in Viçosa, Minas Gerais state, Brazil (2007).

$(\mathrm{F}=50.00 ; \mathrm{p}=0.01)$ and hindtarsus $(\mathrm{F}=20.83 ; \mathrm{p}=0.04)$ were longer in Cryptanura sp. than in H. clavigera (Table 1). Holymenia clavigera has a wasp-shape (Figure 2A) with a slightly longer body than Cryptanura sp. (Table 1). The antennae of both species are long measuring 80 and $86.73 \%$ of the body for $H$. clavigera and Cryptanura sp., respectively (Figure $2 \mathrm{~A}$ and $\mathrm{B}$ ). Hindfemur and hindtarsus are longer for both species.

Both species have similar body colour (Figure $2 \mathrm{C}$ and D). The head (Figure $2 \mathrm{E}$ and F) and thorax (Figure 2 $\mathrm{G}$ and $\mathrm{H}$ ) have a set of white spots which contrast with their dark eyes, head and the hind and dorso-lateral sides of their thorax. The abdomen of both species is entirely red (Figure $2 \mathrm{I}$ and $\mathrm{J}$ ). The ovipositor sheath of Cryptanura sp. females is salient with $3.2 \pm 0.8 \mathrm{~mm}$ long but no body structures or appendices on the bug resembled the ovipositor of the wasp. Their fore and hind wings are hyaline with salient nervures.

The colour pattern of the antennomers, fore, mid and hind legs was also similar between $H$. clavigera and Cryptanura sp. with two dominant colours on the antenna (black and white) and two on the legs (yellow and red) for both insects (Figure 3). Their antennae are dark with a whitish band towards its apex (the white band comprises segment 5 in the bug, and 2 in the ichneumonid wasp).

At our field site, foragers of both species moved solitarily about the forest floor, searching in and above leaf litter. The foraging period for $H$. clavigera and Cryptanura sp. were synchronised with the latter showing intense foraging behaviour. This wasp remained resting on the substrate (fresh or dry leaves and branches), on average, $7.00 \pm 2.30$ seconds $(n=6)$, while $H$. clavigera spent more time on their substrate $(28.20 \pm 3.10$ seconds) $(\mathrm{n}=10)$ that was composed exclusively of fresh leaves. However, when disturbed, the bug spent less than $3 \mathrm{sec}-$ onds until rapidly flying away. In resting moments, an active vibration behaviour by the antennae was observed for $H$. clavigera such as its model did. When the bug was in flight, the white stripe along the sutural margin causes the forewing to appear very narrow, resembling the thicker fore-costal margin of the wasp.

\section{Discussion}

The sampling scheme made it possible to observe a frequency-dependent relationship because the abundance of the model Cryptanura sp. was almost fourfold that of the mimic, H. clavigera. Theory predicts that the benefit of mimicry depends on the abundance of the model and it is more effective when the ranges of the mimic overlap that of the model (Pilecki and O'Donald, 1971; Merrill and Elgar, 2000; Pfennig et al., 2001). This frequency-dependent relationship is an important prerequisite for Batesian mimicry by increasing the opportunity of learning by predators. However, some mimics such as ants not always follow this pattern because they may nest independently of the model and these social insects can develop defense mechanisms against predators (Ito et al., 2004). Heteroptera insects may bite their antagonist but this is not true for phytophagous coreids such as $H$. clavigera who have no defensive apparatus and when disturbed, only flew away.

Some premises upon which Batesian mimicry is based (Huheey, 1964; Rettenmeyer, 1970) were attained in the present study such as the mimic should be less abundant than the model, the mimic should be found at the same place and time as the model and the model and mimic should be conspicuous or readily seen by potential predators. Although other premises were not proven experimentally, they can be assumed as being the nonpalatability to predators by the model, the palatability by the mimic and the learning or associate non-palatability with the colour pattern of the model by predators. Some Hymenoptera (e.g. ants) are considered to be unfavourable as prey for vertebrate predators because of their mass aggression, defensive chemicals, strong mandibles and painful stings (Redford, 1987) as tested for Lasius spathepus Wheeler (Hymenoptera: Formicidae) against 
Table 1 - Morphometric parameters (mm) ( \pm SE) of Holymenia clavigera (Heteroptera: Coreidae) and Cryptanura sp. (Hymenoptera: Ichneumonidae) collected by sweeping vegetation in a fragment of native forestry at the Federal University of Viçosa in Viçosa, Minas Gerais state, Brazil.

\begin{tabular}{|c|c|c|c|}
\hline Parameters & Holhymenia clavigera $(n=4)$ & Cryptanura sp. $(\mathrm{n}=12)$ & Contrast (F ratio) \\
\hline Total antenna length ${ }^{\mathrm{a}}$ & $16.00 \pm 0.40$ & $12.75 \pm 0.45$ & $29.13 *$ \\
\hline $\mathrm{A} 1^{\mathrm{b}}$ & $0.85 \pm 0.15$ & $5.65 \pm 0.25$ & $271.06^{*}$ \\
\hline $\mathrm{A} 2^{\mathrm{b}}$ & $3.05 \pm 0.05$ & $2.15 \pm 0.05$ & $162.00^{*}$ \\
\hline $\mathrm{A} 3^{\mathrm{b}}$ & $3.85 \pm 0.15$ & $4.95 \pm 0.25$ & 14.23 \\
\hline $\mathrm{A} 4^{\mathrm{b}}$ & $3.25 \pm 0.05$ & - & - \\
\hline $\mathrm{A} 5^{\mathrm{b}}$ & $5.00 \pm 0.40$ & - & - \\
\hline Head width & $2.50 \pm 0.00$ & $2.95 \pm 0.15$ & 6.40 \\
\hline Head length & $2.75 \pm 0.05$ & $1.40 \pm 0.10$ & $145.80^{*}$ \\
\hline Vertex width $^{\mathrm{c}}$ & $1.20 \pm 0.00$ & $1.35 \pm 0.05$ & 2.00 \\
\hline Eye length & $0.75 \pm 0.05$ & $1.25 \pm 0.05$ & $50.00^{*}$ \\
\hline Eye width & $0.80 \pm 0.00$ & $0.80 \pm 0.10$ & 0.20 \\
\hline Ocelli length & $0.20 \pm 0.00$ & $0.20 \pm 0.00$ & 0.20 \\
\hline Ocelli width & $0.20 \pm 0.00$ & $0.20 \pm 0.00$ & 0.00 \\
\hline Thorax lenght & $5.25 \pm 0.15$ & $5.75 \pm 0.25$ & 2.94 \\
\hline Thorax width & $4.00 \pm 0.00$ & $2.35 \pm 0.50$ & $18.30^{*}$ \\
\hline Forefemur length & $5.75 \pm 0.25$ & $3.55 \pm 0.35$ & $26.16^{*}$ \\
\hline Foretibia length & $6.60 \pm 0.20$ & $4.25 \pm 0.15$ & $60.50^{*}$ \\
\hline Foretarsi length $^{\mathrm{d}}$ & $10.20 \pm 0.20$ & $6.25 \pm 0.25$ & 0.016 \\
\hline Midfemur length & $3.10 \pm 0.10$ & $2.00 \pm 0.10$ & $88.36^{*}$ \\
\hline Midtibia length & $4.25 \pm 0.45$ & $3.55 \pm 0.55$ & 0.97 \\
\hline Midtarsi length $^{\mathrm{d}}$ & $7.75 \pm 0.25$ & $5.40 \pm 0.60$ & 6.23 \\
\hline Hindfemur length & $2.95 \pm 0.25$ & $2.85 \pm 0.75$ & $152.20^{*}$ \\
\hline Hindtibia length & $3.00 \pm 0.10$ & $2.55 \pm 0.15$ & 13.07 \\
\hline Hindtarsi length $^{\mathrm{d}}$ & $3.15 \pm 0.15$ & $5.10 \pm 0.40$ & $20.83 *$ \\
\hline Forewing length & $14.05 \pm 0.85$ & $12.25 \pm 0.75$ & 2.52 \\
\hline Hindwing length & $10.15 \pm 0.15$ & $7.85 \pm 0.35$ & $36.48^{*}$ \\
\hline Forewing width & $3.55 \pm 0.35$ & $3.65 \pm 0.25$ & 0.054 \\
\hline Hindwing width & $2.70 \pm 0.30$ & $1.55 \pm 0.55$ & 3.36 \\
\hline Abdomen width & $3.80 \pm 0.20$ & $2.15 \pm 0.05$ & $64.05^{*}$ \\
\hline Body length $^{\mathrm{e}}$ & $20.00 \pm 0.20$ & $14.70 \pm 0.40$ & $140.45 *$ \\
\hline
\end{tabular}

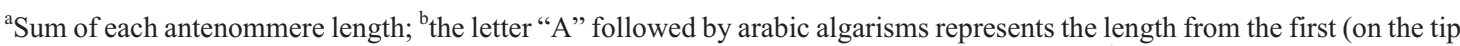
of the antenna) to the sixth (on the basis of the antenna) antenommere; ${ }^{\mathrm{c}}$ distance between eyes; ${ }^{\mathrm{d}}$ sum of tarsomeres; etotal sum of the head (without antenna), thorax and abdomen length; * Significantly at $\mathrm{p}<0.05$ by the F test.

Japanese treefrogs (Taniguchi et al., 2005). Painful stings are absent in ichneumonid wasps, but they can use their long ovipositor as a defensive apparatus, biting their enemies continuously. This last should also be the main defensive apparatus for the ichneumonid wasp.

The mimicry between $H$. clavigera and Cryptanura sp. might have evolved in relation to avian predation be- cause any other natural enemy was observed using, as food source, adult bugs. For this reason, the colour pattern of the body of the ichneumonid wasp including appendages such as legs and antennae was copied by the mimic bug. This suggests the importance of visual cues, which are important tools for hunting prey by visuallyoriented predators (Goldsmith, 1990), to avoid predation. 

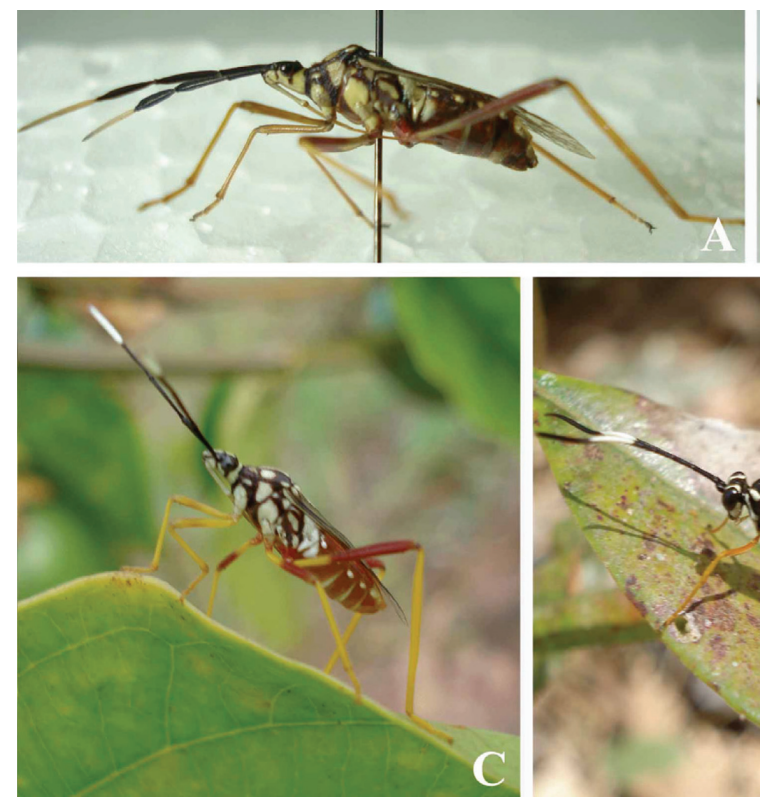
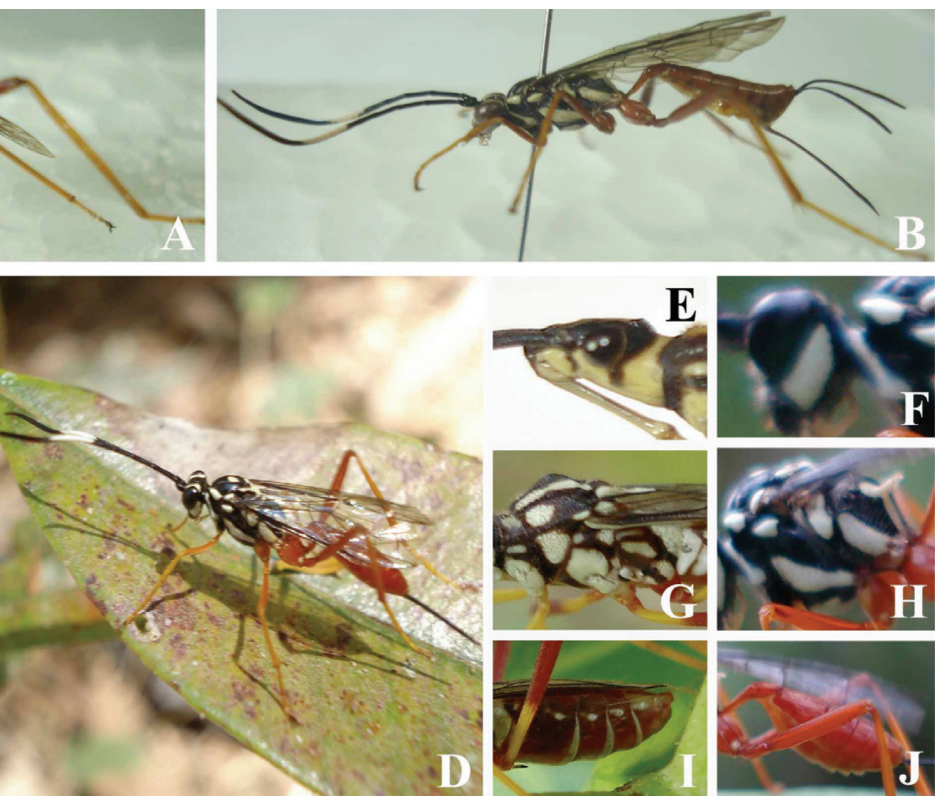

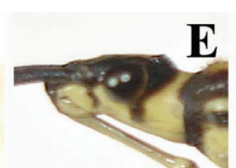

$4 \mathrm{~F}^{3}$
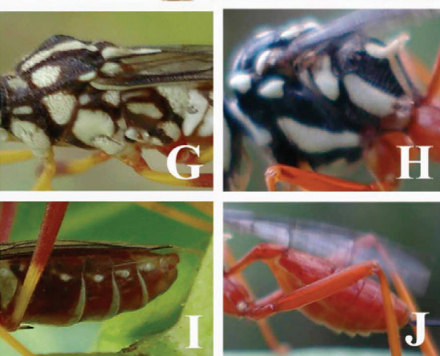

Figure 2 - The mimic Holymenia clavigera (Heteroptera: Coreidae) and its model, Cryptanura sp. (Hymenoptera: Ichneumonidae). Lateral view of H. clavigera (A) and Cryptanura sp. (B) adults mounted. Adult females of H. clavigera (C) and Cryptanura sp. (D) on field. Lateral view of the head of H. clavigera (E) and Cryptanura sp. (F). Lateral view of the thorax of H. clavigera $(\mathrm{G})$ and Cryptanura sp. $(\mathrm{H})$ and lateral view of the abdomen of H. clavigera (I) and Cryptanura sp. (J).

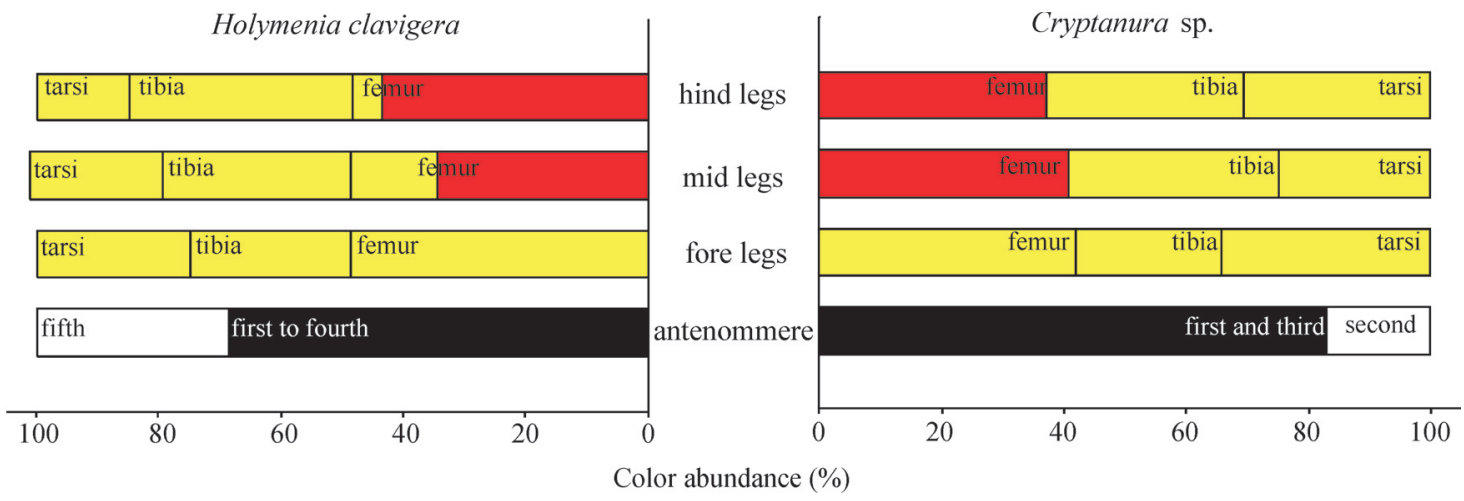

Figure 3 - Colour pattern of body parts of Holymenia clavigera (Heteroptera: Coreidae) and Cryptanura sp. (Hymenoptera: Ichneumonidae). Colour abundance was obtained through measuring (in $\mathrm{mm}$ ) the lengths of each antenommere, hind, mid and fore legs and quantifying the abundance of colours (in $\mathrm{mm}$ ) for each item than this data were transformed in percentage.

Even so, this remains to be studied in future. Insectivorous avian predators have an important role in the balance of food webs in several environmental systems (Merrill and Elgar, 2000) and other studies involving hymenopterans as models also relate cases of mimicry to avoid vertebrate predators (Harris, 1978; Merrill and Elgar, 2000).

The visual resemblances between $H$. clavigera and Cryptanura sp. also extended to behaviour despite their very different ecology. The antennal tips of Cryptanura sp. were used very rapidly to touch the host substrate, with the antennae sweeping repeatedly from laterally to medially as also reported for Echthrus reluctator (Linnaeus) (Hymenoptera: Ichneumonidae) (Laurenne et al., 2009) when foraging concealed hosts. These movements were showed also for $H$. clavigera, suggesting that specific foraging signals from the ichneumonid wasp were identically assumed by the bug. Movements by antennae of Heteroptera may be associated to important ecological cues as for predation (Lemos et al., 2005), alert (Sant'Ana et al., 1997; Thomas and Manica, 2005) or courtship process where the females can reject (or not) sexual partners according to the signals used (Awan, 1988; Capone et al., 1995; Wang and Millar, 2000; Moraes et al., 2005). However, the antennal behaviour of $H$. clavigera did not seem to be linked with any of the described cases what indicates that this bug must spend energy moving its antennae exclusively to mimic the 
foraging behaviour of the ichneumonid wasp. This is in line with several works which emphasise that some Batesian mimics of Hymenoptera should exhibit close behavioural convergence with their models. The mimetic hoverflies, Sphecomyia vittata (Wiedemann), Ceriana signifera (Loew), Tenthredomyia abbreviate (Loew) and Spilomyia hamifera Loew hold their antennae in positions which suggest the geniculate antennae of wasps (Waldbauer, 1970) and the dronefly Eristalis tenax (Linnaeus) (Diptera: Syrphidae) was able to mimic the flight behaviour of honeybees (Golding et al., 2001).

The mimicry reported was based on morphological and behavioural similarities between $H$. clavigera and Cryptanura sp. despite its sympatric occurrence. The degree of palatability of these insects to potential predators remains to be confirmed. However, the field-observed signals strongly suggest that the similarities between these species represent a mimicry relationship.

Acknowledgments - We appreciate the help of the Coordenação de Aperfeiçoamento de Pessoal de Nível Superior (CAPES), Conselho Nacional de Desenvolvimento Científico e Tecnológico (CNPq) and the Fundação de Amparo à Pesquisa do Estado de Minas Gerais (FAPEMIG) for the financial support.

\section{References}

AWAN, MS., 1988. Development and mating behaviour of Oechalia schellenbergii (Guérin-Méneville) and Cermatulus nasalis (Westwood) (Hemiptera: Pentatomidae). Journal of the Australian Entomological Society, vol. 27, p. 183-187.

BATES, HW., 1862. Contributions to an insect fauna of the Amazon valley. Lepidoptera: Heliconidae. Transactions of the Linnean Society of London, vol. 23, p. 495-566.

CAPONE, TA., 1995. Mutual preference for large mates in green stink bugs, Acrosternum hilare (Hemiptera: Pentatomidae). Animal Behaviour, vol. 49, p. 1335-1344.

EVANS, MA., 1965. Mimicry and the Darwinian heritage. Journal of the History of Ideas, vol. 26, p. 211-220.

FLACH, A., MARSAIOLI, AJ., SINGER, RB., AMARAL, MCE., MENEZES, C., KERR, WE., BATISTA-PEREIRA, LG. and CORREAA, AG., 2006. Pollination by sexual mimicry in Mormolyca ringens: a floral chemistry that remarkably matches the pheromones of virgin queens of Scaptotrigona sp. Journal of Chemical Ecology, vol. 32, p. 59-70.

FRANKS, DW. and NOBLE, J., 2002. The origins of mimicry rings. In Artificial Life VIII: Proceedings of the Eighth International Conference on Artificial Life. Massachusetts: MIT Press. p. 186-191.

FRANKS, DW. and NOBLE, J., 2004. Batesian mimics influence mimicry ring evolution. Proceedings of the Royal Society of London Series B: Biological Sciences, vol. 271, p. 191-196.

GOLDING, YC., ENNOS, AR. and EDMUNDS, M., 2001. Similarity in flight behaviour between the honeybee Apis mellifera (Hymenoptera: Apidae) and its presumed mimic, the dronefly Eristalis tenax (Diptera: Syrphidae). Journal of Experimental Biology, vol. 204, p. 139-145.

GOLDING, YC., EDMUNDS, M. and ENNOS, AR., 2005. Flight behaviour during foraging of the social wasp Vespula vulgaris (Hymenoptera: Vespidae) and four mi- metic hoverflies (Diptera: Syrphidae) Sericomyia silentis, Myathropa florea, Helophilus sp. and Syrphus sp. Journal of Experimental Biology, vol. 208, p. 4523-4527.

GOLDSMITH, TH., 1990. Optimization, constraint, and history in the evolution of eyes. The Quarterly Review of Biology, vol. 65 , p. 281-322.

HARRIS, AC., 1978. Mimicry by a longhorn beetle, Neocalliprason elegans (Coleoptera: Cerambycidae), of its parasitoid, Xanthocryptus novozealandicus (Hymenoptera: Ichneumonidae). New Zealand Entomologist, vol. 6, p. 406-408.

HUHEEY, JE., 1964. Studies of warning colouration and mimicry. IV. A Mathematical model of model-mimic frequencies. Ecology, vol. 45, p. 185-188.

ITO, F., HASHIM, R., HUEI, YS., KAUFMANN, E., AKINO, T. and BILLEN, J., 2004. Spectacular Batesian mimicry in ants. Naturwissenschaften, vol. 91, p. 481-484.

LAURENNE, N., KARATOLOS, N. and QUICKE, DLJ., 2009. Hammering homoplasy: Multiple gains and losses of vibrational sounding in cryptine wasps (Insecta: Hymenoptera: Ichneumonidae). Biological Journal of the Linnean Society, vol. 96, p. 82-102.

LEMOS, WP., ZANUNCIO, JC. and SERRÃO, JE., 2005. Attack behaviour of Podisus rostralis (Heteroptera: Pentatomidae) adults on caterpillars of Bombyx mori (Lepidoptera: Bombycidae). Brazilian Archives of Biology and Technology, vol. 48, p. 42-48.

LORENZI, MC., CERVO, R., ZACCHI, F., TURILLAZZI, S. and BAGNÈRES, AG., 2004. Dynamics of chemical mimicry in the social parasite wasp Polistes semenowi (Hymenoptera: Vespidae). Parasitology, vol. 129, p. 643-651.

MARANGON, LC., SOARES, JJ. and FELICIANO, ALP., 2003. Florística arbórea da Mata da Pedreira, município de Viçosa, Minas Gerais. Revista Árvore, vol. 27, p. 207215.

MERRILL, DN. and ELGAR, MA., 2000. Red legs and golden gasters: Batesian mimicry in Australian ants. Naturwissenschaften, vol. 87, p. 212-215.

MORAES, MCB., LAUMANN, RA., COKL, A., BORGES, M., 2005. Vibratory signals of four Neotropical stink bug species. Physiological Entomology, vol. 30, p. 175-188.

PEREIRA, AIA., SMITH, DR., ZANUNCIO, JC. and SERRÃO, JE., 2009. Life history notes on the sawfly Haplostegus nigricrus Conde (Hymenoptera: Pergidae) on Psidium guajava (Myrtaceae) in Minas Gerais state, Brazil. Proceedings of the Entomological Society of Washington, vol. 111, p. 795-806.

PFENNIG, DW., HARCOMBE, WR. and PFENNIG, KS., 2001. Frequency-dependent Batesian mimicry. Nature, vol. 410 , p. 323.

PILECKI, C. and O'DONALD, P., 1971. The effects of predation on artificial mimetic polymorphisms with perfect and imperfect mimics at varying frequencies. Evolution, vol. 55 , p. 365-370.

RAMALHO, FS., WANDERLEY, PA., MALAQUIAS, JB., RODRIGUES, KCV., SOUSA, JVS. and ZANUNCIO, JC., 2009. Temperature-dependent development rates of Bracon vulgares, a parasitoid of boll weevil. Phytoparasitica, vol. 37, p. 17-25.

REIS, MA., ZANETTI, R., SCOLFORO, JRS., FERREIRA, MZ. and ZANUNCIO, JC., 2008. Sampling of leaf-cutting ant nests (Hymenoptera: Formicidae) in eucalyptus plantations using quadrant and prodan methods. Sociobiology, vol. 50, p. 21-29. 
RETTENMYER, CW., 1970. Insect mimicry. Annual Review of Entomology, vol. 15, p. 43-74.

SANT'ANA, J., BRUNI, R., ABDUL-BAKI, AA. and ALDRI$\mathrm{CH}, \mathrm{J} .$, 1997. Pheromone-induced movement of nymphs of the predator, Podisus maculiventris (Heteroptera: Pentatomidae). Biological Control, vol. 10, p. 123-128.

SANTOS, GP., ZANUNCIO, JC., PIRES, EM., PREZOTTO, F., PEREIRA, JMM. and SERRÃO, JE., 2009. Foraging of Parachartergus fraternus (Hymenoptera: Vespidae: Eponini) on cloudy and sunny days. Sociobiology, vol. 53, p. 431-441.

TANIGUCHI, K., MARUYAMA, M., ICHIKAWA, T. and ITO, F., 2005. A case of Batesian mimicry between a myrmecophilous staphylinid beetle, Pella comes, and its host ant, Lasius (Dendrolasius) spathepus: an experiment using the Japanese treefrog, Hyla japonica as a real predator. Insect Sociaux, vol. 52, p. 320-322.

THOMAS, LK. and MANICA, A., 2005. Intrasexual competition and mate choice in assassin bugs with uniparental male and female care. Animal Behaviour, vol. 69, p. $275-281$.

VIANNA, UR., PRATISSOLI, D., ZANUNCIO, JC., LIMA, ER., BRUNNER, J., PEREIRA, FF. and SERRÃO, JE., 2009. Insecticide toxicity to Trichogramma pretiosum (Hymenoptera: Trichogrammatidae) females and effect on descendant generation. Ecotoxicology, vol. 18, p. 180186.

WAHL, DB., 1993. Family Ichneumonidae. In GOULET, H and HUBER, JT. (Eds.). Hymenoptera of the world: An identification guide to families. Ottawa: Research Branch Agriculture Canada Publication. p. 395-442.

WALDBAUER, GP., 1970. Mimicry of hymenopteran antennae by Syrphidae. Psyche, vol. 77, p. 45-49.

WANG, Q. and MILLAR, JG., 2000. Mating behaviour and evidence for male-produced sex pheromones in Leptoglossus clypealis (Heteroptera: Coreidae). Annals of the Entomological Society of America, vol. 93, p. 972-976.

YU, DS. and HORSTMANN, K., 1997. A catalogue of World Ichneumonidae (Hymenoptera). Part 1. Subfamilies Acaenitinae to Ophioninae. Memoirs of the American Entomological Institute, vol. 58, p. 1-763.

ZANUNCIO, JC., LOPES, ET., LEITE, HG., ZANETTI, R., SEDIYAMA, CS. and FIALHO, MCQ., 2004. Sampling methods for monitoring the number area of colonies of leaf cutting ants (Hymenoptera: Formicidae) in Eucalyptus plantations in Brazil. Sociobiology, vol. 44, p. 337344.

ZÚÑIGA-RAMÍREZ, RJ., 2004. The taxonomy and biology of the Polycyrtus species (Hymenoptera: Ichneumonidae, Cryptinae) of Costa Rica. Contributions of the American Entomological Institute, vol. 33, p. 1-159. 